\title{
Developing Life Skills in Children: A Road Map for Communicating with Parents
}

\author{
Bibb Hubbard \\ Learning Heroes
}

Research has found that healthy learning and development depend upon the integration of children's social, emotional, cognitive, and academic growth at home and in school. To inform communication with parents and guardians about the role of schools in developing these skills, Learning Heroes conducted research among parents of $K-8$ public school students. They found parents expect schools to reinforce the development of "life skills" in their children, are as likely to agree with the potential benefits as the potential risks of schools' involvement, and push back on formal grading of their children in the development of these skills.

\section{INTRODUCTION}

Research shows that children's social, emotional, cognitive, and academic development are deeply intertwined, like the strands of a rope, and come together to create successful adults. Schools have always taught skills like respect, getting along well with others, and self-control, especially in the early grades. But we are now entering a unique moment, where there is greater awareness and acceptance of the need to integrate the social and emotional, cognitive, and academic aspects of learning into daily instruction. As a result, school systems are thinking in explicit, intentional ways about how to combine social, emotional, cognitive, and academic development at home, at school, and in after-school settings so that all children can succeed in school and in life.

To help educators understand how parents feel and talk about the development of these skills in their children, and the role they see for schools and after-school settings, Learning Heroes, a nonprofit organization that serves to inform and equip parents to be advocates for their children and partners in their education, conducted a series of 10 focus groups and a nationwide survey of more than 2,000 parents who have children in K-8 public schools. The study focused on the parents of elementary and middle school students because this is when parents are first likely to be introduced to these concepts by schools.

"Life skills", as most parents call the skills and traits they associate with their child's overall development, are seen as interconnected, a view backed by science. Parents think of these as "life skills" because they prepare their children for success academically and for the long haul. And parents provide many reasons for why these skills are beneficial: from helping their child learn, to being a good community member, to preparing them for the workforce, to countering the effects of peer pressure and bullying. Parents expect a dialogue with schools about these skills, if framed as helping their child succeed academically and in the larger world. 
However, Learning Heroes found that as educators look to inform and engage parents about a range of research-based instructional practices that may seem new and different to what they experienced growing up or than their children have been exposed to, there is opportunity for parents to embrace these teaching strategies, but also risk for them to become confused, frustrated, and to feel that these new approaches push the limits of what is appropriate for schools. The research revealed that half of parents surveyed identify with both the potential benefits and risks of schools and after-school settings having a role in children's social, emotional, cognitive, and academic development. Their acceptance could fluctuate depending on how educators handle four key issues:

\section{Skills Begin at Home, Are Reinforced in School}

Parents believe that home and school both have a role in children's social, emotional, cognitive, and academic development, but not an equal one. In the survey, parents are more likely to view home as the place where these skills are "taught" (95\%) and schools as the place where they are "reinforced" (92\%). The focus groups reveal even more strident opinions on this topic, with parents seeing themselves as primarily responsible for their child's development, and the school serving as a partner. "I think their role is to go along with the parent and be a bridge," says a Dayton, OH, parent. "It's not their job to raise my child. That's my job." "Don't tell me something my child should be doing in my house," says an Oakland, CA, parent.

\section{Key Consideration}

How can educators ensure that they are partnering with parents and not overstepping their role?

\section{Real-World Examples Bring the Strategies to Life}

Parents are not education experts. They need real-life examples of what integrating social, emotional, cognitive, and academic development looks like in instructional practice. Video clips showing students engaged in such learning can be a powerful way to make these concepts concrete. Parents also respond favorably when social, emotional, cognitive, and academic development are integrated into the teaching of academic subjects like reading, writing, and math. This allays parents' concerns that these skills will be taught at the expense of academic progress. For example, 84 percent of parents, including 88 percent of African-American parents and 86 percent of Hispanic parents are "very" or "somewhat interested" in having their school use strategies and activities to reinforce these skills and traits throughout the school day.

\section{Key Consideration}

How can educators provide parents with concrete examples of school practices that support social, emotional, cognitive, and academic development so that parents see the benefits for their individual child?

\section{Measurement Misgivings}

While parents expect schools to reinforce these skills in school, simply put, parents object to having their child graded, rated, or assessed on the development of social, emotional, and cognitive skills. More than a third of parents worry about their child being labeled $(35 \%)$ or graded $(34 \%)$ on the development of these skills and traits and the potential implications for their child's future opportunities. Only 16 percent indicate it would be helpful to get a separate grade on their child's report card to understand their child's progress on these skills. Instead, parents want to hear from teachers about how their child is doing in the form of parent-teacher conferences, folder notes, emails, and more regular communication, particularly if there's a problem. Overwhelmingly, parents trust their child's teachers, their child, and their pediatricians for information about their child's social, emotional, cognitive, and academic development. But they view this information as highly personal and often subjective. They question whether such skills and traits can be objectively and accurately measured. And they don't think grades and ratings can give them the detailed, qualitative information they need to know. "There shouldn't be a grade on how you feel or what you think," says a Wilmington, NC, parent. 
Parents feel deeply responsible for their children's well-being and success in school and in life. Parents believe school is the means to a successful life and view school through that lens. With this responsibility, parents hold many roles, but prioritize their children's happiness over everything else. The intensity parents feel about helping their children develop life skills shapes and influences many of the daily tasks required in raising their children.

\section{Key Consideration}

How can educators reconcile their desire for measures to know if schools and children are progressing with the red flag this poses for parents?

\section{"Edu-jargon" Doesn't Translate}

The language educators typically use to talk about social, emotional, cognitive, and academic learning to parents and what parents understand it to mean are often quite different. For example, while many parents conceptually support the idea of persevering and taking on challenges, the word "grit" strikes them as negative and is not in their vocabulary. "Grit almost seemed like fighting through things," says a Dayton, OH, parent. "Not everything needs to be fought through." Words like "curiosity" and "selfawareness," which to educators may seem benign, may cause parents to worry about their children's psychological and physical safety. As one Pennsylvania mother notes: "I teach my son that curiosity killed the cat."

\section{Key Consideration}

How can educators stay grounded in the scientific research and use everyday language to translate key concepts for parents in ways that resonate?

\section{PARENTS IN THE DRIVER'S SEAT, BUT WELCOME HELP}

Parents stand at the ready to help their children get through life's challenges - from the little bumps in the road to the big stuff. But when it comes to diagnosing how their child is developing, they are more worried about their social and emotional well-being than about their academic performance: first, because they have a rosy picture of their children's academic achievement; and second, because of the increasing anxiety they have about the world their children encounter outside the home.

Previous Learning Heroes research shows that nine in 10 parents believe their children are achieving at or above grade level, though national data suggest otherwise, giving them a misplaced sense of confidence about their children's achievement.

In contrast, parents of K-8 public school students are more concerned about a number of other factors related to raising their children: 58 percent worry "a lot" or "some" about their child's happiness and emotional well-being, 58 percent worry about their child facing peer pressure, 50 percent worry about their child being bullied, and 50 percent worry about their child's ability to cope and manage stress, as compared to 46 percent who worry about gaining the knowledge and skills needed to be ready for college and 41 percent who worry about their child being on track with the academic expectations for their grade.

\section{Parents Own the Responsibility for Their Child's Social, Emotional, Cognitive, and Academic Development, but Partner with Teachers to Get the Job Done}

When it comes to in-school success for their children, parents see themselves as primarily responsible (only $12 \%$ of parents report the teacher as the individual with the most responsibility for their child's inschool success). But parents do expect schools to play a role in developing their children socially, emotionally, cognitively, and academically. In fact, 80 percent say it is "absolutely essential" or "very important" that their child's school has high expectations for learning and academic progress, and almost as many (78\%) say it is "absolutely essential" or "very important" for their child's school to have high expectations for social and emotional development. They see these skills as interconnected and important for success in school and in life. 
Moreover, parents expect to see certain behaviors if their child is developing these skills, most notably respect: "treats others with respect and understanding" (71\%) and "respects other people and cultures" (66\%). More than six in 10 parents also expect children who have developed these skills and traits that they prioritize to: speak up for themselves; continually develop intellectually, emotionally, and socially; assume responsibility for their own thoughts and actions; and strive for excellence by working hard, staying on task, and being motivated. (Figure 1)

\section{FIGURE 1 \\ BEHAVIORS PARENTS EXPECT FROM THEIR CHILDREN}

Q: What behaviors do you expect from a child who has these skills and traits?

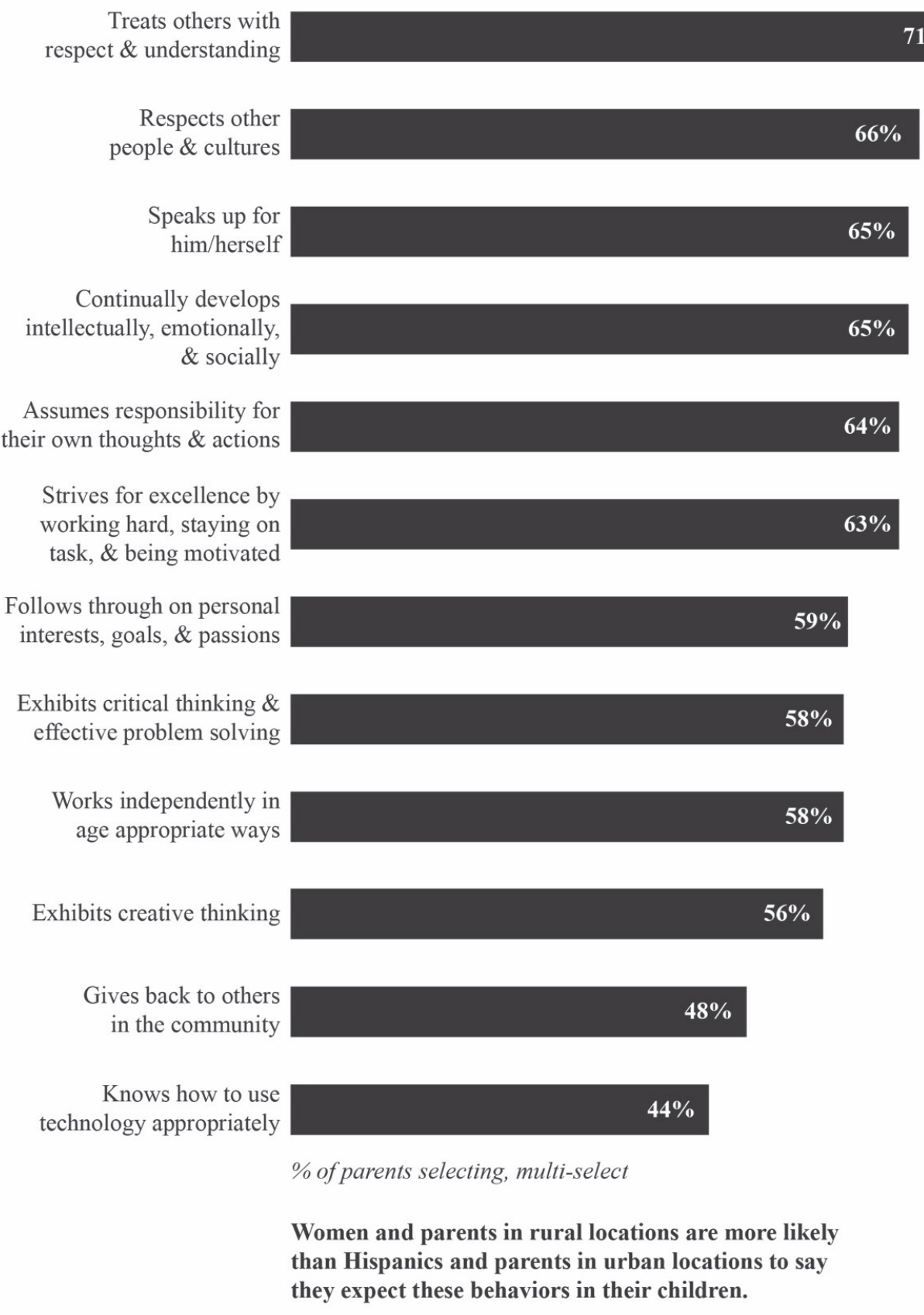

36 Journal of Higher Education Theory and Practice Vol. 19(3) 2019 
Because of this, parents are open to school's communicating about these skills and traits if they are framed as helping their child succeed academically and in the larger world. Indeed, in focus groups, many parents say they are still developing these skills themselves and see them as vital for their own success and that of their children.

\section{While Parents Expect Schools to Be Part of the Equation, the Foundation Starts at Home}

When parents think about the skills and traits that are most important for their child to develop, more than nine in 10 expect both school and home to play a role. "It's a partnership for me," says one Oakland, CA, parent. "All beautiful as long as you keep me in tow with what you're doing." At the same time, parents view schools as playing a supporting role and one with limits. "I want a teacher, but not a parent," says one Wilmington, NC, parent. Says another Wilmington, NC, parent, "Teachers, if they influence, I expect them to have respect for others' beliefs, not push their own." Hispanic parents, in particular, think social, emotional, cognitive, and academic skills and the values associated with them begin at home. While 95 percent of Hispanic parents think these skills should be taught at home, only 89 percent think they should be taught at school. Parents don't want schools to supplant or overstep their role in the social, emotional, cognitive, and academic development of their children.

\section{Developing These Skills Is Deeply Personal}

For parents, their children come first. They feel deeply and personally responsible for their children's development. It isn't a conversation to have at the bus stop. When getting information about these issues, parents place trust in those who are in their inner circle or have specific expertise - their child's teacher, family members, pediatricians, and academic experts. When asked whom they trust for information about social, emotional, cognitive, and academic development, 84 percent identify their child, 76 percent their child's teacher, and 79 percent pediatricians or other health care professionals. (Figures $2 \& 3$ ) 


\section{FIGURE 2}

\section{WHO PARENTS TRUST}

Q: How much do you trust the following sources when it comes to information about this topic?

Your child(ren)

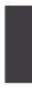

Your parents/family

Pediatrician or other health care professionals

Your child's teacher(s)

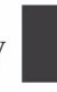

$81 \%$

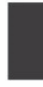

$79 \%$

Education/learning experts

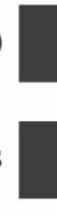

Principal

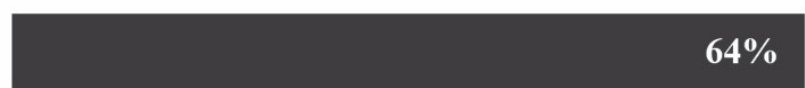

Your friends

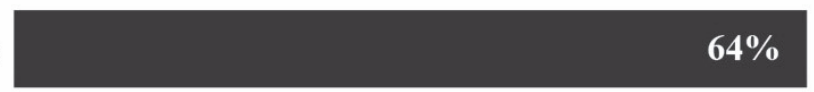

Parent groups

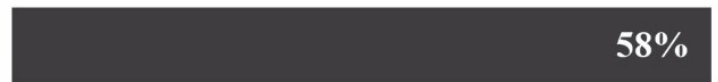

Leader of a place of worship
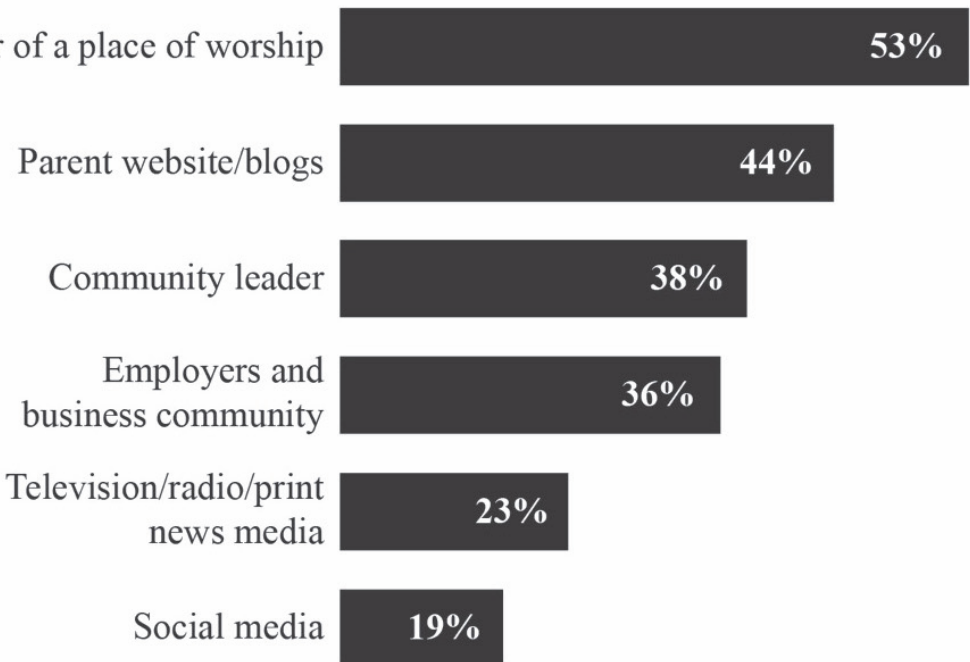

$\%$ of parents rating trust $4 / 5$ out of 5

No major differences across subgroups. 
FIGURE 3

TEACHER FEEDBACK MOST HELPFUL

Q: Which resources are most helpful to you as a parent to support your child in this type of learning?

Personalized information about my child from my child's teacher detailing what I can do at home to

support my child's development

Websites with parent guides, and activities for children and families

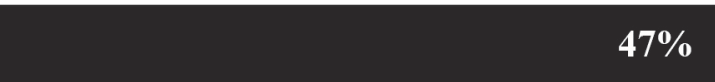

Face-to-face advice from other parents (informally, or through community groups)

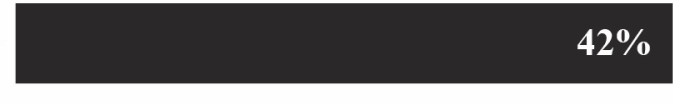

Print materials (provided by the teacher, school or community organizations)

Getting advice from my parents $28 \%$

Online advice from other parents (through social media like Facebook, Twitter, etc.) $27 \%$

Videos (from experts showing developmental milestones)

\section{$26 \%$}

Games and/or apps $25 \%$

$\%$ of parents selecting, multi-select

No major differences across subgroups.

\section{PARENTS ARE PROTECTORS}

Parents know that life can be challenging. They worry about their children facing a hard world out there. They view themselves as protectors and defenders of their child. Because of this, if they think their child is threatened, or if their core beliefs about what their child needs are challenged, they hold even 
more firmly to their personal beliefs. How educators communicate to parents about the role of schools and after-school settings in helping develop social, emotional, cognitive, and academic skills, given the "protector mindset," will be key.

\section{A Little Bit of Information Goes a Long Way-Context and Messages Matter}

Parents are constantly weighing a variety of factors to determine what is best for their child at any given moment. While parents intuitively see the importance of social, emotional, cognitive, and academic skills, a majority identify with both the potential benefits and the risks of schools' involvement. This is especially true for men, Hispanics, and conservatives.

We showed parents 10 statements that underscored the potential benefits of schools' involvement in developing social, emotional, cognitive, and academic skills and traits and 11 statements that addressed potential downsides of the school's role. (Tables $1-4$ )

We found half of all parents either agree with both sides of the issue or generally agree with the potential benefits and also with a couple of the potential risks.

\section{TABLE 1}

\begin{tabular}{|l|c|}
\hline $\begin{array}{l}\text { Statements that underscore potential risks of schools' involvement in } \\
\text { developing social, emotional, cognitive, and academic skills }\end{array}$ & $\begin{array}{c}\text { \% of parents } \\
\text { who resonate } \\
\text { with risks }\end{array}$ \\
\hline $\begin{array}{l}\text { "This could lead to my child being labeled for life because they had a behavior } \\
\text { issue that was determined by someone who might not understand him/her." }\end{array}$ & $50 \%$ \\
\hline $\begin{array}{l}\text { "I worry that there will be 'standards' and that students will be graded or judged } \\
\text { on their feelings." }\end{array}$ & $48 \%$ \\
\hline $\begin{array}{l}\text { "I am concerned that the government will collect personal data on my child, which } \\
\text { is a violation of privacy." }\end{array}$ & $48 \%$ \\
\hline $\begin{array}{l}\text { "When you go to get a job, bosses are not interested in your emotions-this is just } \\
\text { another example of schools babying our children, so they are not prepared for the } \\
\text { real world." }\end{array}$ & $43 \%$ \\
\hline $\begin{array}{l}\text { "Schools should be focused on academics-reading, writing, math, and science-- } \\
\text { and not teaching children how to think or what to feel." }\end{array}$ & $43 \%$ \\
\hline $\begin{array}{l}\text { Statements that underscore potential benefits of schools' involvement in } \\
\text { developing social, emotional, cognitive, and academic skills }\end{array}$ & $\begin{array}{l}\text { \% of parents } \\
\text { who resonate } \\
\text { with benefits }\end{array}$ \\
\hline $\begin{array}{l}\text { "Teaching real-world skills and traits helps students be better prepared for college, } \\
\text { the workforce, and life." }\end{array}$ & $83 \%$ \\
\hline $\begin{array}{l}\text { "Children need these skills and traits to work with others, solve social problems, } \\
\text { and make communities better in the future." }\end{array}$ & $81 \%$ \\
\hline $\begin{array}{l}\text { "When children have learning mindsets and skills, they are motivated and know } \\
\text { how to learn, and are more likely to thrive in school." }\end{array}$ & $80 \%$ \\
\hline $\begin{array}{l}\text { "Children equipped with social, emotional, and [academic/cognitive] skills and } \\
\text { traits are ready to learn and do better in school." }\end{array}$ & $80 \%$ \\
\hline $\begin{array}{l}\text { "If parents and families join forces with school and after school to develop these } \\
\text { skills and traits, all aspects of education will improve." }\end{array}$ & $79 \%$ \\
\hline $\begin{array}{l}\text { "We live in a very different world today, with more social media, bullying, } \\
\text { violence, and suicide-making it even more important for teachers and schools to } \\
\text { reinforce skills and traits that help students and their parents deal with these issues } \\
\text { effectively." }\end{array}$ & $79 \%$ \\
\hline
\end{tabular}


As one Colorado Springs, CO, parent says: "I want school to create a positive academic atmosphere. I want the focus to be on academics, need them to learn, don't want the soft squishy psychological stuff." Says a Wilmington, NC, parent: "Do I want my daughter's teacher to teach social awareness or relationship skills? I'd rather they teach her math."

\section{TABLE 2 \\ STATEMENTS ABOUT RISK THAT HAVE TRACTION}

Q: Here's a little bit more information - some reasons why people oppose school and afterschool programs reinforcing skills and traits like those that you identified as important earlier in the survey. Please indicate if you agree or disagree with each personally.

\begin{tabular}{|c|c|c|c|c|}
\hline$\%$ who agree with each of the following: & Total & $\begin{array}{l}\text { Identifies } \\
\text { with Risks }\end{array}$ & $\begin{array}{l}\text { Identifies } \\
\text { with Benefits } \\
\text { and Risks }\end{array}$ & $\begin{array}{l}\text { Identifies } \\
\text { with Benefits }\end{array}$ \\
\hline $\begin{array}{l}\text { This could lead to my child being labeled } \\
\text { for life because they had a behavior issue } \\
\text { that was determined by someone who } \\
\text { might not understand him/her. }\end{array}$ & $35 \%$ & $70 \%$ & $50 \%$ & $11 \%$ \\
\hline $\begin{array}{l}\text { I worry there will be "standards" and that } \\
\text { students will be graded or judged on their } \\
\text { feelings. }\end{array}$ & $34 \%$ & $65 \%$ & $48 \%$ & $13 \%$ \\
\hline $\begin{array}{l}\text { I am concerned that the government will } \\
\text { collect personal data on my child, which } \\
\text { is a violation of privacy. }\end{array}$ & $34 \%$ & $65 \%$ & $48 \%$ & $12 \%$ \\
\hline $\begin{array}{l}\text { This all sounds nice, but let's face it, } \\
\text { there are a lot more serious issues that } \\
\text { cause social, emotional, and behavior } \\
\text { problems in our schools, and no program } \\
\text { will fix that. }\end{array}$ & $30 \%$ & $71 \%$ & $45 \%$ & $7 \%$ \\
\hline $\begin{array}{l}\text { Schools should be focused on academics } \\
\text {-- reading, writing, math, and science -- } \\
\text { and not teaching children how to think } \\
\text { or what to feel. }\end{array}$ & $29 \%$ & $80 \%$ & $43 \%$ & $5 \%$ \\
\hline $\begin{array}{l}\text { When you go to get a job, bosses are not } \\
\text { interested in your emotions - this is just } \\
\text { another example of schools babying our } \\
\text { children, so they are not prepared for } \\
\text { the real world. }\end{array}$ & $28 \%$ & $69 \%$ & $43 \%$ & $6 \%$ \\
\hline $\begin{array}{l}\text { This sounds like psychological } \\
\text { manipulation, where teachers are } \\
\text { therapists and our kids are the patients. }\end{array}$ & $23 \%$ & $75 \%$ & $35 \%$ & $1 \%$ \\
\hline $\begin{array}{l}\text { Less Effective: } \\
\text { Schools and afterschool programs should } \\
\text { stay out of teaching these skills, because it } \\
\text { is the job of parents. }\end{array}$ & $18 \%$ & $59 \%$ & $28 \%$ & $1 \%$ \\
\hline & hite & old indicate & & \\
\hline
\end{tabular}


TABLE 3

STATEMENTS ABOUT BENEFITS THAT RESONATE

Q: You identified the skills and traits that are most important to you. Here are some reasons why people support reinforcing these skills and traits in school and after-school programs. Please indicate if you agree or disagree with each.

"Real-world skills" for college,
work and life resonates ACROSS
the spectrum.
$\%$ who agree with each of the following:

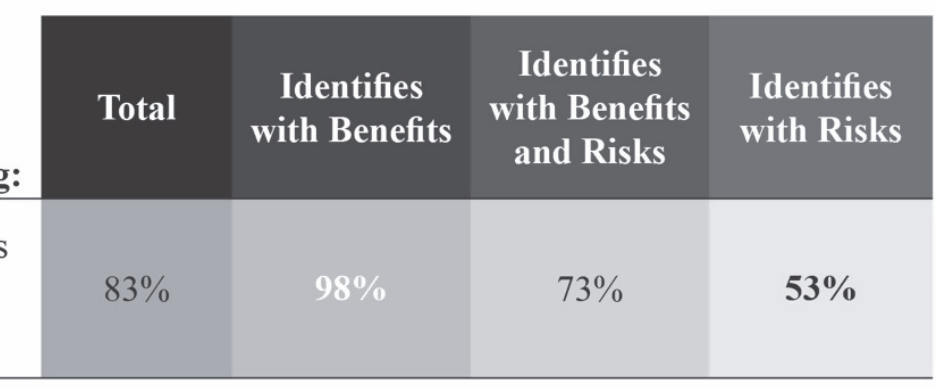

Teaching real-world skills and traits helps students be better prepared for college, the workforce, and life.

These messages resonate with some parents, not all.

\% who agree with each of the following:

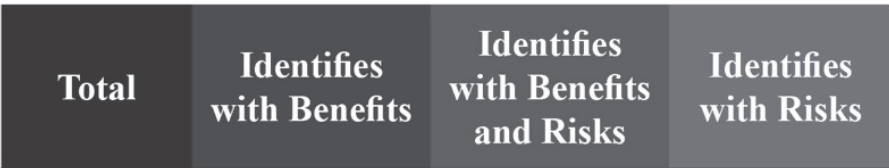

Children need these skills and traits to work with others, solve social problems, and make communities better in the future.

When children have learning mindsets and skills, they are motivated and know how to learn, and are more likely to thrive in school.

Children equipped with social, emotional, and [academic/cognitive] skills and traits are ready to learn and do better in school.

If parents and families join forces with school and after-school to develop these skills and traits, all aspects of education will improve.

We live in a very different world today, with more social media, bullying, violence, and suicide - making it even more important for teachers and schools to reinforce skills and traits that help students and their parents deal with these issues effectively.

Women and parents who live in rural areas are more likely to agree with these messages.

White / bold indicates higher / lower vs subgroups

*cognitive

**academic 
TABLE 4

REACTIONS BY DEMOGRAPHIC ARE NOT CUT AND DRY

\begin{tabular}{|c|c|c|c|c|c|}
\hline \multicolumn{2}{|c|}{ Identifies with Benefits } & \multicolumn{2}{|c|}{$\begin{array}{c}\text { Identifies with } \\
\text { Benefits \& Risks }\end{array}$} & \multicolumn{2}{|c|}{ Identifies with Risks } \\
\hline Black & $48 \%$ & Black & $48 \%$ & Black & $4 \%$ \\
\hline White & $46 \%$ & White & $47 \%$ & White & $7 \%$ \\
\hline Hispanic & $37 \%$ & Hispanic & $54 \%$ & Hispanic & $9 \%$ \\
\hline Male & $34 \%$ & Male & $56 \%$ & Male & $10 \%$ \\
\hline Female & $49 \%$ & Female & $46 \%$ & Female & $5 \%$ \\
\hline Urban & $39 \%$ & Urban & $54 \%$ & Urban & $7 \%$ \\
\hline Suburban & $45 \%$ & Suburban & $47 \%$ & Suburban & $7 \%$ \\
\hline Rural & $49 \%$ & Rural & $46 \%$ & Rural & $5 \%$ \\
\hline Religious & $37 \%$ & Religious & $55 \%$ & Religious & $8 \%$ \\
\hline Not religious & $49 \%$ & Not religious & $46 \%$ & Not religious & $6 \%$ \\
\hline Trump voter & $33 \%$ & Trump voter & $57 \%$ & Trump voter & $10 \%$ \\
\hline Clinton voter & $51 \%$ & Clinton voter & $44 \%$ & Clinton voter & $5 \%$ \\
\hline Conservative & $35 \%$ & Conservative & $54 \%$ & Conservative & $10 \%$ \\
\hline Moderate & $43 \%$ & Moderate & $51 \%$ & Moderate & $5 \%$ \\
\hline Liberal & $54 \%$ & Liberal & $41 \%$ & Liberal & $4 \%$ \\
\hline
\end{tabular}

\section{A LITTLE INFORMATION GOES A LONG WAY, BUT GRADES CAN GO TOO FAR}

How educators communicate about the range of skills and traits that science supports as important for all children will be key in helping parents understand why these skills and traits matter for their individual child and the role teachers and schools play in partnering with families to develop them. Otherwise, educators risk unintended consequences that could lead to confusion, frustration, and ultimately pushback among parents.

There is no magic language - but we know certain words and phrases generate a negative, even visceral, response. Those to watch out for include "judging or grading students on their feelings," "teaching children how to think," or anything that suggests usurping the "job of parents." (Table 5) 


\section{TABLE 5 \\ PARENTS REACT TO CERTAIN WORDS AND PHRASES}

Certain language and phrases can evoke different types of responses in parents

\begin{tabular}{l} 
"Support" "social, emotional, and cognitive/ \\
academic development" \\
\hline "Learn, thrive and succeed" \\
\hline "Cognitive" or "academic" \\
\hline When parents and educators "join forces" \\
\hline Being "ready to learn" and "engage in school" \\
\hline Need to "communicate" \\
\hline "Prepared" and being better prepared
\end{tabular}

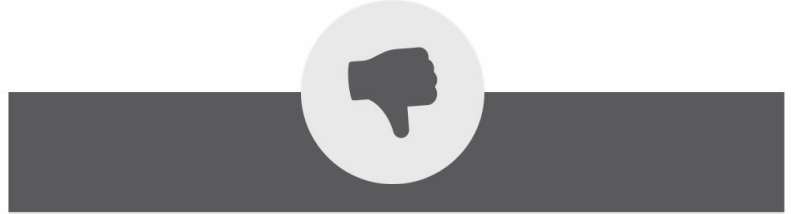

"Students should not be judged or graded on their feelings" is a real trouble spot-especially among parents who are conflicted about the role of schools or are more likely to agree with potential risks

"Teach children how to think" gets attention

"Not school's place," should stay "focused on academics" and this is the "job of parents"

\section{Reinforce Why This Matters for Their Child}

\section{Recognizing What This Looks Like in Practice Is Low}

While parents expect schools and after-school settings to support the development of social, emotional, cognitive, and academic skills, they typically don't know what this instruction looks like in practice. Parents need the details about what their child is experiencing in class and the benefits to their child.

A few parents in focus groups refer to specific examples from their child's school. "Where my kids go to school, they have character building. These lessons are good, and they reinforce what I taught my children," says one Dayton, OH, parent. "They care enough to teach my child interpersonal skills," says an Oakland, CA, parent. "They send out a weekly reader that they're teaching kids this, 'No put downs.' I was taught to attack; my son is taught not to do that. I think it's cool." Other parents aren't sure this is happening in their child's school or are skeptical that such efforts are being practiced consistently.

During the focus groups, parents viewed short, two-minute videos of schools that integrate social, emotional, cognitive, and academic development into the learning environment and into teaching academic content. Parents resonated with videos that showed children engaging or interacting with such content. Overall, parents are most open to practices that integrate these skills across academic subjects 
and into the learning environment. Says a Wilmington, NC, parent, "If they're infusing it into the existing lessons, they're still teaching math, and, somehow, they're infusing this in. If they can do that, that's great." By contrast, when they see specific classes or programs dedicated to "social and emotional learning," they worry whether schools already have too much on their plates and if this will take time away from academics. "Where are you going to get the time?" asks a Wilmington, NC, parent. "They're already overbooked. Why are you going to throw more things on teachers, when these skills are already taught at home?"

\section{Measuring These Skills is Complicated}

Parents are particularly concerned about how these skills will be measured, especially if it involves their own child. Parents first look to communications from teachers about attitudes, behaviors, and skills development, then to feedback from their child. (Figure 3)

\section{FIGURE 3}

\section{PARENTS DON'T WANT THEIR CHILD GRADED OR RATED}

Q: What type of feedback is most helpful to you as a parent to understand your child's progress in this type of learning?

Regular communication from teachers about attitude, behaviors and skill development

Feedback from your child, when you ask "how was school?" or "what did you learn today?"

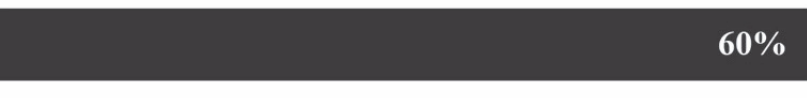

Discussion at parent-teacher conferences

A parent guide on which skills and traits are age-appropriate and the indicators to look for at home

A personalized development plan, with milestones and regular progress reports

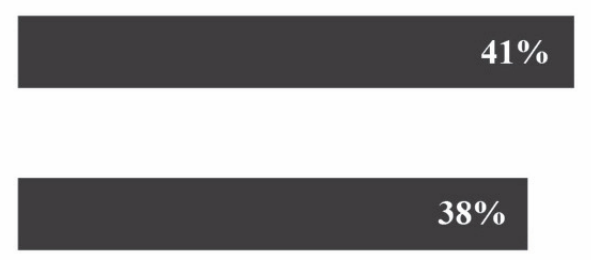

Getting a separate grade on your child's report card

\section{$16 \%$}

Schools distributing a set of expectations for the social, emotional, and academic learning taking place at each grade level

Schools distributing a set of standards for the social, emotional, and academic learning talking place at each grade level

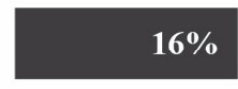

\section{$15 \%$}

\section{$12 \%$}

$\%$ of parents selecting, multi-select

No major differences across subgroups. 
Instead of another set of "standards," parents want regular communication from teachers about their children's progress on these skills and traits - and immediate notification if there's a problem. They want that contact to be personal, in the form of parent-teacher conferences, emails, and qualitative narratives.

For parents whose schools are implementing a program that integrates social, emotional, cognitive, and academic learning, when asked what type of feedback is most helpful to understand their child's progress, 60 percent say "regular communication from teachers about attitude, behaviors, and skill development," and 54 percent say "discussions at parent-teacher conferences" and "feedback from your child, when you ask 'how was school?' or 'what did you learn today?"

Very few (16\% or less) are interested in getting formal grades or expectations related to social and emotional development. Even fewer (12\%) believe it is helpful for schools to distribute a set of standards for social, emotional, and academic learning taking place at each grade level.

In focus groups, parents express concern about the subjective nature of ratings and grades for such skills. "How could they be graded to a standard?" asks one Wilmington, NC, parent.

Parents also question whether detailed checklists of an individual child's development are realistic, given class sizes and the demands on teachers' time. And they say grades and ratings do not give them enough specific feedback about their individual child. "You want more of a personal note," says a Philadelphia parent. "I want you to tell me about MY child. Not just lists you've come up with."

Parents in focus groups are more open to information about whether schools are creating environments conducive to healthy learning and development, including surveys of parents, teachers, and students themselves, if they're old enough. But the idea of holding schools and teachers accountable for the social, emotional, cognitive, and academic development of their children is not something they've thought about and almost universally evokes a negative response.

\section{A COMMUNICATIONS ROAD MAP}

Most parents are not experts on the topic of social, emotional, cognitive, and academic development but they do care deeply about and respond to the language of skills and traits. And parents know their own child best. How the conversation about their child unfolds matters. Some skills resonate more than others. Even when parents dislike certain terms, they may support the underlying concept when presented to them clearly.

The national survey asked parents to select up to 10 skills and traits that they think are the most important for their child to develop, based on 60 that appear in a number of frameworks related to social, emotional, cognitive, and academic development, as well as words that parents volunteered during an initial set of six focus groups.

Throughout the research, we explored the connections and gaps between these two lenses: the educator and the parent. The final set of four focus groups probed how parents define or think about each term and which related concepts and terms resonate with them. (Table 6) 
TABLE 6

IDENTIFYING SKILLS \& TRAITS THAT PARENTS PRIORITIZE

Q: Please select up to 10 skills and traits that you think are the most important for your child to have.

\begin{tabular}{|c|c|c|c|c|}
\hline $\begin{array}{l}\text { Learning from } \\
\text { mistakes }\end{array}$ & $\begin{array}{c}\text { Managing } \\
\text { emotions \& } \\
\text { behavior }\end{array}$ & Perseverance & $\begin{array}{l}\text { Taking on } \\
\text { challenge }\end{array}$ & Prosocial behavior \\
\hline Communication & $\begin{array}{c}\text { Responsible } \\
\text { decision-making }\end{array}$ & Social awareness & Love of learning & Perspective-taking \\
\hline Respect & Problem-solving & Relationship skills & Resilience & Executive function \\
\hline Confidence & Teamwork & Adaptability & Engaged learning & Coping \\
\hline Self-esteem & Self-control & Conflict resolution & Tolerance & Managing stress \\
\hline Setting goals & Empathy & Focus & Curiosity & Being organized \\
\hline Courage & Dedication & Flexibility & $\begin{array}{l}\text { Emotional } \\
\text { intelligence }\end{array}$ & Patience \\
\hline Self-motivation & Social skills & Self-management & $\begin{array}{l}\text { Learning } \\
\text { mindsets }\end{array}$ & Leadership \\
\hline Kindness & Critical thinking & $\begin{array}{c}\text { Creative } \\
\text { problem-solving }\end{array}$ & Intelligence & Listening \\
\hline Compassion & Persistence & $\begin{array}{l}\text { Self-directed } \\
\text { learning }\end{array}$ & Grit & Accepting others \\
\hline Independence & Caring & Optimism & Self-regulation & $\begin{array}{l}\text { Academic } \\
\text { mindsets }\end{array}$ \\
\hline Self-awareness & Gratitude & Mindfulness & $\begin{array}{l}\text { Cognitive } \\
\text { regulation }\end{array}$ & Growth mindsets \\
\hline
\end{tabular}

The roadmap that follows is designed to help educators, practitioners, and researchers bridge the gap between the everyday language that parents use, and the more technical and academic terms often used by the field. When communicating with parents about these issues, the following are a few rules of the road to keep in mind. 


\section{Parents View Social, Emotional, Cognitive, and Academic Development as Inextricably Linked}

With the option of selecting up to 10 skills and traits, parents typically selected an average of nine as the most important for their child to have. Parents prioritized a mix of social, emotional, cognitive, and academic skills, in line with their views that these skills and traits are inextricably linked in children's development. (Figures 4 \& 5)

FIGURE 4

PARENTS TOP SKILLS \& TRAITS

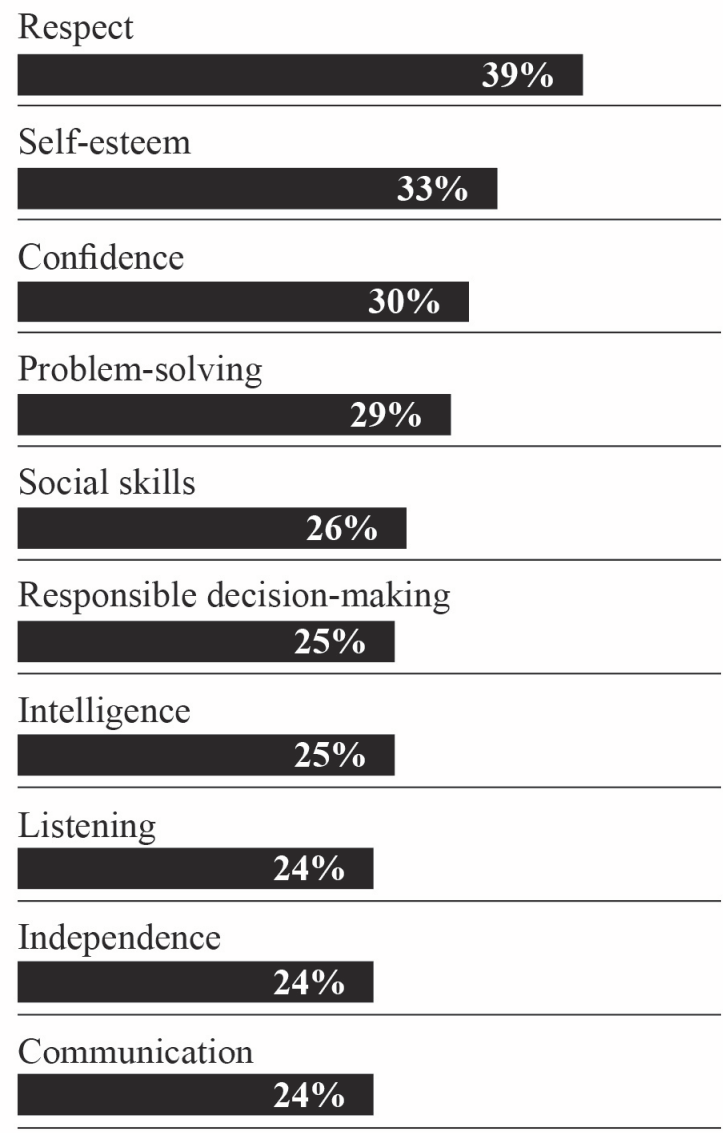

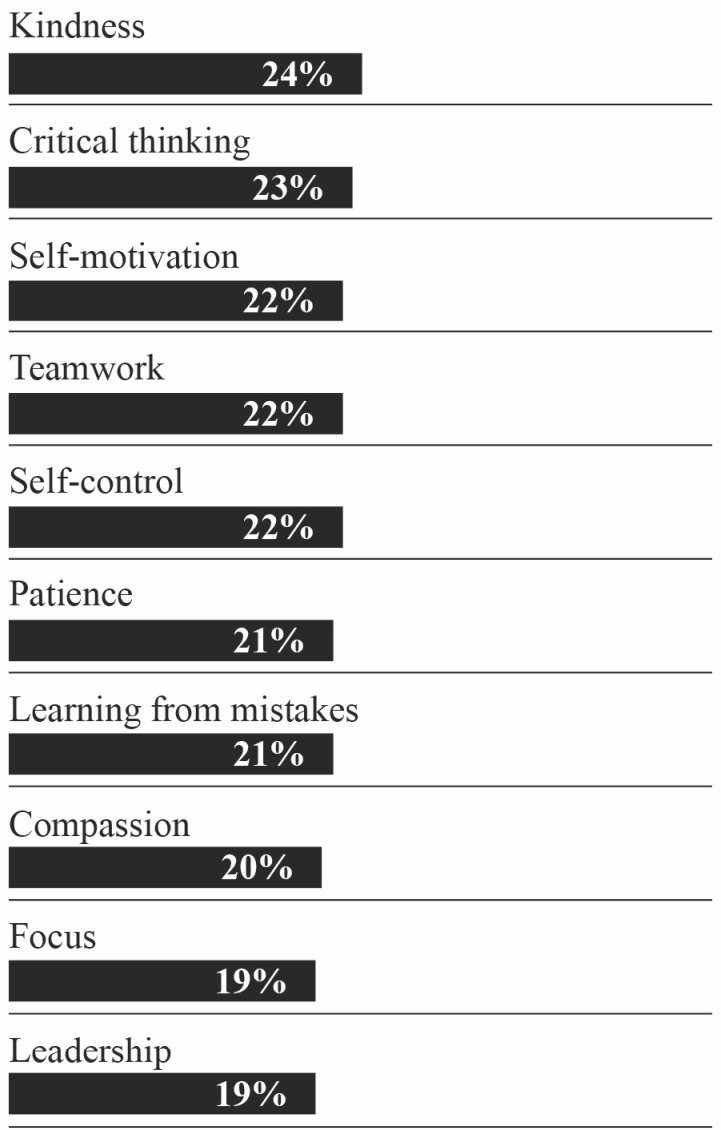

Urban parents are less likely to prioritize self-esteem, problem-solving, kindness, critical thinking, and compassion.

Hispanic parents are less likely to prioritize listening, critical thinking, and self-control. 
FIGURE 5

ONE IN 10 PARENTS OR FEWER SELECT THESE SKILLS \& TRAITS

\begin{tabular}{|c|}
\hline Optimism \\
\hline $\mathbf{1 0} \%$ \\
\hline Tolerance \\
\hline $\mathbf{1 0} \%$ \\
\hline Persistence \\
\hline $\mathbf{1 0} \%$ \\
\hline Curiosity \\
\hline $\mathbf{1 0 \%}$ \\
\hline Resilience \\
\hline $\mathbf{8 \%}$ \\
\hline Coping \\
\hline $\mathbf{8 \%}$ \\
\hline Growth mindset \\
\hline $\mathbf{8 \%}$ \\
\hline Mindfulness \\
\hline $\mathbf{8 \%}$ \\
\hline Self-directed learning \\
\hline $\mathbf{7 \%}$ \\
\hline Flexibility \\
\hline $\mathbf{7 \%}$ \\
\hline
\end{tabular}

Learning mindsets

$7 \%$

Self-regulation

$6 \%$

Prosocial behavior

$4 \%$

Cognitive regulation

$4 \%$

Grit

$3 \%$

Executive function

$3 \%$

Perspective-taking

$3 \%$

Hispanic parents are more likely to prioritize optimism, tolerance, and grit.

Tables 7 and 8 show that many of these words are simply unfamiliar or too academic for parents, while others elicit an unintended, negative response. 
TABLE 7

PARENT LENS: HOW PARENTS REACT TO THE TOP SKILLS \& TRAITS

\begin{tabular}{|c|c|c|}
\hline Top Skills/Traits & Parent Lens (Qualitative) & Subgroup Differences (Quantitative) \\
\hline Respect & $\begin{array}{l}\text { To some parents, respect is "earned;" } \\
\text { they associate it with respect for } \\
\text { authority. } \\
\text { Parents view respect differently from } \\
\text { kindness, compassion, or empathy, } \\
\text { saying that children can feel these } \\
\text { emotions toward someone without } \\
\text { necessarily respecting them. }\end{array}$ & $\begin{array}{l}\text { Respect is more important for women } \\
(41 \%) \text { than for men }(33 \%) \text {. } \\
\text { Parents who see both the benefits and } \\
\text { risks of teaching such skills in school } \\
\text { focus on speaking up for oneself and } \\
\text { developing personal responsibility more } \\
\text { than on "respect for others." }\end{array}$ \\
\hline $\begin{array}{l}\text { Self-esteem } \\
\text { Confidence } \\
\text { Independence } \\
\text { Self-motivation }\end{array}$ & $\begin{array}{l}\text { "Self-esteem" ranked slightly higher } \\
\text { in the survey, but "confidence" is the } \\
\text { conversation starter. } \\
\text { Parents view "confidence" as internal } \\
\text { and something children project, and } \\
\text { "self-esteem" as more tied to self-worth. }\end{array}$ & $\begin{array}{l}\text { Self-esteem and independence are more } \\
\text { important for women ( } 35 \% \text { and } 26 \% \text {, } \\
\text { respectively) than for men ( } 28 \% \text { and } \\
19 \%) \text {. }\end{array}$ \\
\hline $\begin{array}{l}\text { Problem-solving } \\
\text { Responsible } \\
\text { decision-making } \\
\text { Intelligence } \\
\text { Critical thinking }\end{array}$ & $\begin{array}{l}\text { Parents say "problem-solving" comes up } \\
\text { everywhere. } \\
\text { They also talk about "analyzing } \\
\text { situations," "setting goals," and "critical } \\
\text { thinking." }\end{array}$ & $\begin{array}{l}\text { Parents of children in grades K-2 are } \\
\text { less likely to rate "responsible decision } \\
\text { making" as important }(21 \%) \text { than } \\
\text { parents of children in grades } 3-5(28 \%) \\
\text { or } 6-8(27 \%) \text {. } \\
\text { Men are more likely than women to } \\
\text { rate "intelligence" as important ( } 28 \% \text { vs } \\
24 \%) \text {. }\end{array}$ \\
\hline $\begin{array}{l}\text { Social skills } \\
\text { Listening } \\
\text { Communication } \\
\text { Teamwork }\end{array}$ & $\begin{array}{l}\text { "Communication" and "social skills" are } \\
\text { terms parents use often, and they value } \\
\text { "listening." }\end{array}$ & $\begin{array}{l}\text { Spanish-dominant parents identify } \\
\text { "communication" as a particularity } \\
\text { important skill ( } 30 \%) \text { and in focus } \\
\text { groups talk about the importance of } \\
\text { having open, trusting communications in } \\
\text { the home. }\end{array}$ \\
\hline $\begin{array}{l}\text { Kindness } \\
\text { Compassion }\end{array}$ & $\begin{array}{l}\text { While many parents think these skills } \\
\text { and traits are important, they are not } \\
\text { rated as highly by parents who mostly } \\
\text { identify with potential risks in schools } \\
\text { playing a role in the development } \\
\text { of social, emotional, cognitive, and } \\
\text { academic skills. }\end{array}$ & $\begin{array}{l}\text { "Kindness" is more important for the } \\
\text { parents of students in grades K-2 and } 3-5 \\
(26 \% \text { and } 24 \% \text {, respectively) than for the } \\
\text { parents of middle school students ( } 20 \%) \text {. } \\
\text { It is much more important for women } \\
(26 \%) \text { than for men }(19 \%) \text {. }\end{array}$ \\
\hline $\begin{array}{l}\text { Self-control } \\
\text { Patience } \\
\text { Focus }\end{array}$ & $\begin{array}{l}\text { Parents describe self-control as "staying } \\
\text { on task" and "having a filter." } \\
\text { Parents talk about resisting temptation } \\
\text { more than being proactive. } \\
\text { Parents don't use "self-regulation, } \\
\text { "self-management," and "self-direction," } \\
\text { as they are viewed as too academic. }\end{array}$ & $\begin{array}{l}\text { "Self-control" is rated less important by } \\
\text { Hispanic parents }(18 \%) .\end{array}$ \\
\hline
\end{tabular}

Other terms identified by parents as being among the top 20 most important skills and traits are "learning from mistakes" (21\%) and "leadership" (19\%). 
TABLE 8

PARENT LENS: HOW PARENTS REACT TO THE TOP SKILLS \& TRAITS NOT AS HIGHLY PRIORITIZED

\begin{tabular}{|c|c|c|}
\hline Skills/Traits & Parent Lens (Qualitative) & Subgroup Differences (Quantitative) \\
\hline Grit & $\begin{array}{l}\text { Most parents aren't familiar with the } \\
\text { term, associating it with "dirt," "hard, } \\
\text { difficult work," "persisting through } \\
\text { challenges and adversity" (which can } \\
\text { have negative connotations) more than } \\
\text { having a positive drive or passion to } \\
\text { persist in achieving a goal. }\end{array}$ & $\begin{array}{l}\text { Hispanic parents are more likely than } \\
\text { those of other races or ethnicities to } \\
\text { rate "grit" as important, but still only } 5 \\
\text { percent did so. }\end{array}$ \\
\hline $\begin{array}{l}\text { Executive } \\
\text { Function }\end{array}$ & $\begin{array}{l}\text { Most parents have never heard of } \\
\text { "executive function." } \\
\text { They understand the importance of } \\
\text { focus, setting goals and strategies, } \\
\text { developing plans to achieve those goals, } \\
\text { being organized, and managing your } \\
\text { time, all of which are related to the } \\
\text { larger concept. }\end{array}$ & $\begin{array}{l}\text { There are no statistically significant } \\
\text { subgroup differences. }\end{array}$ \\
\hline Curiosity & $\begin{array}{l}\text { Parents view curiosity as both positive } \\
\text { and negative. } \\
\text { While it may be good to be curious } \\
\text { about what you are learning in school, } \\
\text { they worry about children being curious } \\
\text { about the wrong or even dangerous } \\
\text { things. }\end{array}$ & $\begin{array}{l}\text { African-American parents }(8 \%) \text { are } \\
\text { less likely than parents of other races } \\
\text { or ethnicities to rate "curiosity" as } \\
\text { important. }\end{array}$ \\
\hline Optimism & $\begin{array}{l}\text { This is not a word parents typically think } \\
\text { of when it comes to their child's devel- } \\
\text { opment. } \\
\text { Parents are particularly resistant to } \\
\text { the notion that traits like "optimism," } \\
\text { "hope," and "zest" can be measured. }\end{array}$ & $\begin{array}{l}\text { Hispanic parents }(13 \%) \text { are more likely } \\
\text { to rate "optimism" as important, and this } \\
\text { is particularly true for Spanish-dominant } \\
\text { parents }(21 \%) \text {. }\end{array}$ \\
\hline Persistence & $\begin{array}{l}\text { Parents are more likely to talk about } \\
\text { their children "sticking with challenges" } \\
\text { or "persevering." }\end{array}$ & $\begin{array}{l}\text { There are no statistically significant } \\
\text { subgroup differences. }\end{array}$ \\
\hline Attachment & $\begin{array}{l}\text { Parents view attachment as an important, } \\
\text { personal bond between parents and } \\
\text { their children and, therefore, as an } \\
\text { inappropriate or even dangerous } \\
\text { word to use when thinking about the } \\
\text { relationships between teachers and } \\
\text { students. }\end{array}$ & This term was not included in the survey. \\
\hline
\end{tabular}




\section{Defining the "It"}

Parents think of social, emotional, cognitive, and academic development as "life skills" (31\%) because they prepare their children for success academically and for the long haul. They prefer this term over "social, emotional, and academic development," "character development," and "social and emotional learning" by at least 2-to-1. (Figure 7)

\section{FIGURE 7}

\section{PARENTS CHOOSE LIFE SKILLS}

Q: Which one term do you prefer to describe the skills and traits that you identified as important?

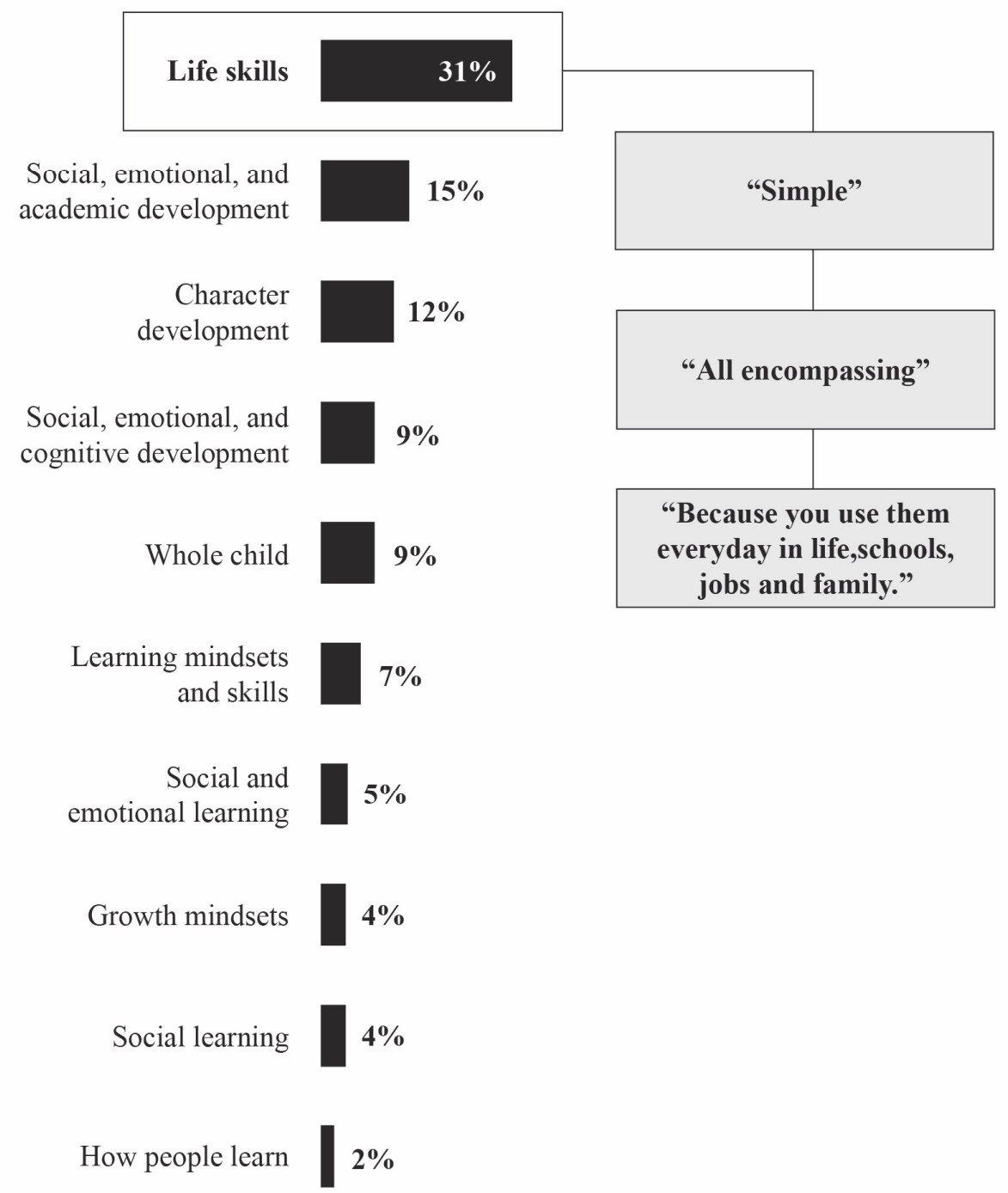

"Life skills" is the preferred term both unaided and by at least 2-to-1 in an aided question.

Preference is consistent across all subgroups. 


\section{Communicating About Skills and Traits: Translating Terms for Parents}

While parents prioritize many of the concepts backed by science, they don't use the same language and often plead for more common vocabulary. Parents strongly prefer everyday talk to terms for skills and traits that they view as academic, technical, or simply unfamiliar. Many conclude that such language is just not intended for them, and, as a result, will ignore communications that use it or will make up a definition if they think they are supposed to know the meaning.

\section{TABLE 8}

\begin{tabular}{|c|c|c|}
\hline Field Says... & Parents Think... & Parents Translation \\
\hline $\begin{array}{l}\text { Resilience } \\
\text { Perseverance } \\
\text { Persistence }\end{array}$ & That their child is unhappy/struggling & $\begin{array}{l}\text { Bouncing back } \\
\text { Sticking with it } \\
\text { Learning from mistakes } \\
\text { Overcoming obstacles }\end{array}$ \\
\hline Grit & Dirt, difficulty, something hard & $\begin{array}{l}\text { Taking on challenges } \\
\text { Pulsing yourself } \\
\text { Learning from efforts } \\
\text { Learning from mistakes }\end{array}$ \\
\hline Executive Function & "Is that going to the bathroom?" & $\begin{array}{l}\text { Organizational skills } \\
\text { Setting goals } \\
\text { Ability to focus } \\
\text { Managing time well }\end{array}$ \\
\hline Self-regulation & $\begin{array}{l}\text { That sounds like my child is going through some } \\
\text { sort of therapy }\end{array}$ & Self-control \\
\hline Growth mindset & $\begin{array}{l}\text { The ability of their child's mind to expand and } \\
\text { grow increases over time as they mature }\end{array}$ & $\begin{array}{l}\text { Learning from mistakes } \\
\text { Hard work pays off } \\
\text { It's all in the effort }\end{array}$ \\
\hline
\end{tabular}

\section{METHODOLOGY}

Phase 1: Landscape analysis, April-May 2017

Desktop research focused on understanding the current around social, emotional, cognitive, and academic learning as it relates to parents; how the topic is now covered in traditional and digital media; and what is known from existing opinion research. 
Phase 2: Parent focus groups, May-June 2017

Six focus groups of parents of K-8 public school students in Dayton, OH; Wilmington, NC; and Oakland, $\mathrm{CA}$, included parents from mixed racial, ethnic, and economic backgrounds. One focus group was conducted in Spanish. The sites were selected to include communities whose school systems already have a strong focus on social, emotional, cognitive, and academic development and those that do not. They also were selected to include a mix of political ideologies. The focus groups were used to understand how parents naturally talk about the skills they believe are most important for their children's success to inform design of a larger, national survey.

Phase 3: National, online survey of 2,026 parents with children in public school, grades K-8, with oversamples of African-American parents (500), Hispanic parents (500), and low-income parents (100). The survey was fielded between August 25 -September 12, 2017 and offered in both English and Spanish.

Phase 4: Four additional parent focus groups in November 2017 in Philadelphia, PA, and Colorado Springs, $\mathrm{CO}$, pressure-tested the survey findings and delved deeper into how parents interpret key words and concepts. One group was conducted in Spanish.

Throughout this process, Learning Heroes and Edge Research worked with more than a dozen collaborating and partner organizations, and with expert advisors, to design the focus group guides and the survey instrument and to review interim findings that helped shape the final report and communications road map.

For the purposes of this report, "parents" includes guardians, caregivers, or any other adult primarily responsible for a child.

\section{ACKNOWLEDGEMENTS}

Learning Heroes is grateful to the Bezos Family Foundation, Einhorn Family Charitable Trust, and the Raikes Foundation for their collaboration and financial support in the creation of this report.

We would also like to thank the team at Edge Research, as well as our writer, Lynn Olson, and the design team at Little House.

And our gratitude goes out to National PTA, National Urban League, UnidosUS, and Univision Communications, for their ongoing partnership, as well as the many individuals and organizations that played a role in the creation of this report: Dr. Marc Brackett, Yale Center for Emotional Intelligence; Dr. Camille Farrington, University of Chicago Consortium on School Research; Dr. Ronald Ferguson, Harvard Kennedy School of Government; Dr. Stephanie Jones, Harvard Graduate School of Education; Dr. Jason Okonofua, University of California, Berkeley; CASEL, Character Lab, Common Sense Media, Communities for Just Schools Fund, Conservative Leaders for Education, Education Trust, EL Education, Forum for Youth Investment, National Black Child Development Institute, National Commission on Social, Emotional, and Academic Development, National Equity Project, and Transcend Education. 